Near Eastern Archaeology

A Reader 
This page intentionally left blank. 


\title{
Near Eastern Archaeology
}

\author{
A Reader
}

Edited by

Suzanne Richard

Winona Lake, Indiana

EISENBRAUNS

2003 
Copyright $@ 2003$ by Eisenbrauns.

All rights reserved.

Printed in the United States of America.

\section{Cataloging-in-Publication Data}

Near Eastern archaeology : a reader / edited by Suzanne Richard. p. $\mathrm{cm}$.

Includes bibliographical references and index.

ISBN I-57506-083-3

I. Archaeology-Middle East-History. 2. Middle East-

Antiquities. I. Richard, Suzanne

$\mathrm{DS}_{5} 6 . \mathrm{N}_{395} 2003$

$939^{\prime} \cdot 4-\mathrm{dc} 2 \mathrm{I}$

2003012571

The paper used in this publication meets the minimum requirements of the American National Standard for Information Sciences-Permanence of Paper for Printed Library Materials, ANSI Z39.48-I984.@ ${ }^{\mathrm{TM}}$ 